\title{
医薬品開発における分子イメージング技術の導入
}

\author{
三好荘介
}

\section{Challenges of Imaging as a Biomarker in Drug Research and Drug}

\author{
Sosuke Miyoshi \\ Bioimaging Research Labs., Astellas Pharma Inc.; 21 Miyukigaoka, Tsukuba, Ibaraki 305-8585, Japan.
}

(Received October 31, 2013)

\begin{abstract}
Positron emission computed tomography (PET) imaging is a clinically translatable technology with the potential to accelerate drug research and development. Therapy monitoring by non-invasive PET imaging study allows a straightforward translation from preclinical to clinical research. In fact, PET imaging is making a major contribution to drug development today and will continue to grow in value. We hereby demonstrate that PET imaging capabilities and our experiences focused on oncology and central nervous system (CNS) therapeutic areas in drug research and development. PET with labeled anticancer drug may be an ideal biomarker for identification of treatment-responsive populations. Using non-invasive PET imaging with labeled anticancer drug, we investigated whether uptake of anticancer drug in tumors is associated with the efficacy. Brain concentration of CNS drug could be obtained according to the radioactivity of PET-labeled CNS drug in brain measured by PET. Usually, blood-brain barrier (BBB) penetration in non-human primates is a good indication for human BBB penetration and we have performed brain PET study in conscious rhesus macaques using special PET camera for non-human primate. Recently, we have successfully identified ${ }^{18} \mathrm{~F}$-fluorodeoxyglucose (FDG) PET is useful as a tool for the predictive imaging biomarker against CNS drug-induced neuronal degeneration/cell death and available in the clinical trial. Finally, we would like to mention that how imaging biomarkers should be applied to clinical trials including investigational trials beyond preclinical study.
\end{abstract}

Key words_ - positron emission tomography (PET); labeled anticancer drug; imaging biomarker

\section{1.はじめに}

医薬品の研究から開発における臨床予測性の向上 を目指したアプローチとして，より臨床予測性の高 い 1）動物モデルの開発や 2) 動物評価方法（検出方 法）の適用が重要な課題である. 前者は実験動物科 学の向上, 後者はヒトと同様の非侵襲的な個体を評 価する方法としてのバイオイメージング技術の応用 が考えられ，これらの融合によるアプローチについ て本稿では紹介したい。われわれはバイオイメージ ング技術の中でも特に positron emission computed tomography (PET)/computer tomography (CT) に 注目して，主にがん領域や中枢領域などを中心にマ ウス/ラットのげっ歯類からサルを用いた霊長類の 前臨床試験でのイメージングバイオマーカーの探索

The author declares no conflict of interest.

アステラス製薬株式会社研究本部バイオイメージング

研究所（テ305-8585 茨城県つくば市御幸が丘 21）

e-mail: sousuke.miyoshi@astellas.com

本総説は, 日本薬学会第 133 年会シンポジウム S30-

204 で発表した内容を中心に記述したものである.
を展開している. 1) すなわち, 臨床開発中の薬剂そ のものを PET 標識したトレーサーを用いることに より，抗がん剤では in vivo 腫瘍微小環境下での腫 瘍移行性を評価することが可能となり，中枢薬では 血中濃度からは予測が難しい脳内濃度予測が可能と なる。これらは前臨床試験のみならず臨床試験まで をつなぐイメージングバイオマーカーとしても大い に活用されるところである。ささらに，最近，薬剤誘 発神経毒性の安全性イメージングバイオマーカーと しての ${ }^{18}$ F-fluorodeoxyglucose (FDG)-PET の可能 性を見い出すことにも成功し，イメージングバイオ マーカーを用いた臨床予測性の高い安全性評価法の 開発にも取り組んでいる. 2 )

\section{2. マウス肺がん同所移植モデルと PET/CT 画}

\section{像評価}

臨床予測性の高い動物モデルの構築を目的に, マ ウス皮下移植モデルではなく，ヒト非小細胞肺がん である Calu-6 細胞をヌードマウスの肺末梢部へ移 植する同所移植モデルを作製した。3) マウス肺がん 
同所移植モデルでは，腫瘍は肺がん患者さんと同様 に肺の内部に存在するため, 従来の皮下移植モデル で行われるノギスによる腫瘍体積評価は適用できな い，そこで，臨床評価方法と同様に，形態画像測定 法である CT による腫瘍体積評価や機能画像測定法 として腫瘍の増殖活性をモニターする ${ }^{18} \mathrm{~F}$-fluorothymidine（FLT）と呼ばれるトレーサーを用いた PET 試験による腫瘍の評価を実施した．Figure 1 に示すように，CT による評価ではヨード系造影剂 のイオパミロンをマウスへ投与し，さらに 3 次元 画像処理（Real INTAGE, CYBERNET SYSTEMS Co., Ltd.) により，緑色に示した腫瘍の周辺部に 腫瘍により誘導された血管新生の様子も鮮明に観察 することができた，さらに，このマウス肺がん同所 移植モデルを用いて，抗がん剂ドセタキセル（タキ ソテール）の抗腫瘍作用に関する薬効評価を実施し たところ，Fig. 2 に示されるように， vehicle 群で は腫瘍増殖がみられたことに対して，ドセタキセル 投与群では経時的な腫瘍の退縮が観察された。さら に，CT による腫瘍の体積変化よりも FLT-PET 試 験による腫瘍の増殖活性に基づく評価の方がより早 期に薬効を捉えることができた．FLT-PET 試験の 結果は，腫瘍の増殖活性を示す Ki-67 染色による病 理評価ともよく一致した。 ${ }^{18} \mathrm{~F}-\mathrm{FLT}$ は DNA を構成 する核酸の 1 つであるチミジンの誘導体であるた
め，細胞分裂が活発な腫瘍では DNA の複製に伴い チミジンの取り込み量が増加する原理より, ${ }^{18} \mathrm{~F}$ FLT は増殖活性と相関した腫瘍内への集積を示 す。また， ${ }^{18} \mathrm{~F}-\mathrm{FLT}$ は核酸トランスポーターにより 細胞内に取り込まれ，チミジンキナーゼ I によるリ ン酸化まではチミジンと同様の動向を示すが, DNA 鎖への合成には取り込まれないため, メ夕ボ リックトラップ作用により細胞内へ蓄積するユニー クなチミジン誘導体でもある。現在，米国では ${ }^{18} \mathrm{~F}$ FLT は investigational new drug（IND）を申請する ことなく臨床で使用できる PET トレーサーとな り，多くの臨床試験の中で FDG についで広くがん 治療に対する効果の判定などに利用されている。し かしながら，肺がんの臨床評価方法としては，簡便 な CT による画像評価法が標準診断方法として確立 されており, Response Evaluation Criteria in Solid Tumors（RECIST）と呼ばれる抗がん剂の抗腫瘍作 用を評価する基準が設けられている。 RECIST は, 臨床現場でより簡便かつ効率的に評価することを目 的として腫瘍の体積評価ではなく腫瘍の長径のみの 一次元評価となっている．複数の腫瘍を持つ患者さ んでは，それぞれの腫瘍長径の和として数值化され る。そこで，CT によるマウス肺がん同所移植モデ ルの評価に関しても RECIST に基づいた CT 画像 による腫瘍長径のみの一次元評価と三次元 CT 画像

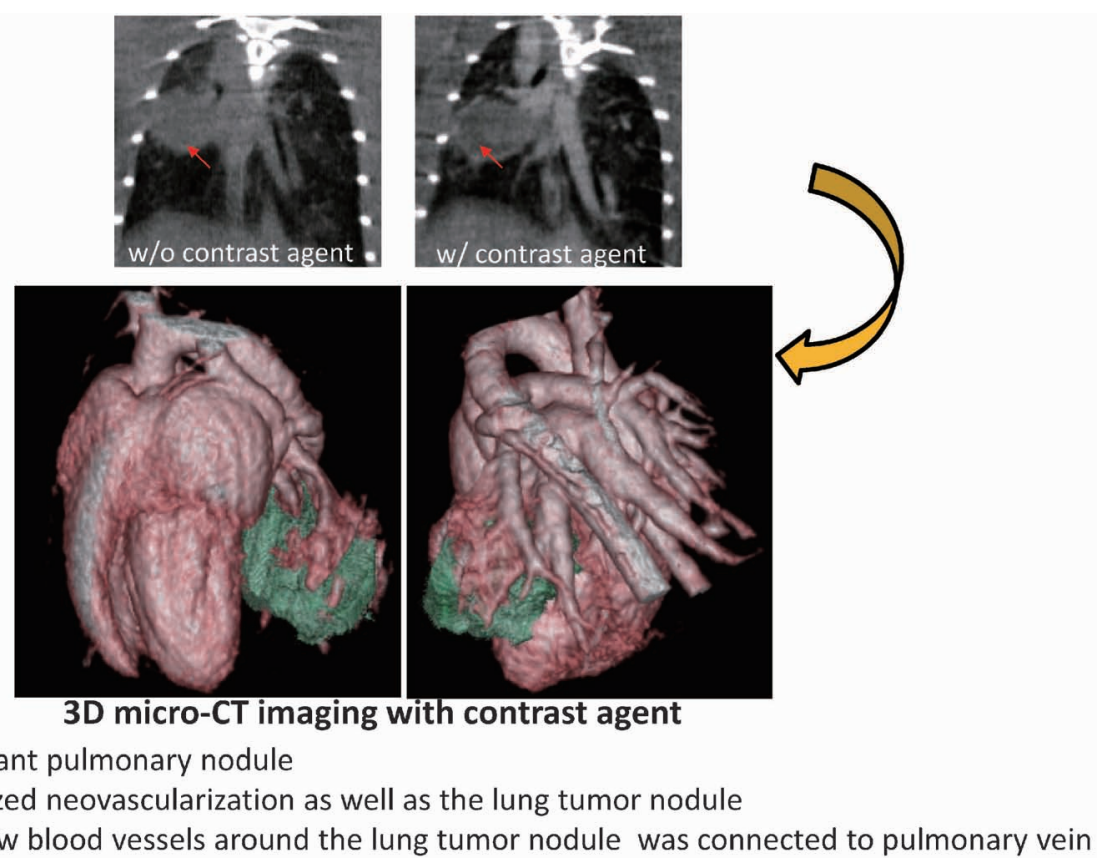

Fig. 1. Micro-CT Imaging of Pulmonary Tumor-induced Neovascularization in Orthotopic Human Xenograft 


\section{Imaging of tumor cell proliferation}

[18F]Fluoro-3'-deoxy-3'-L-fluorothymidine (FLT)
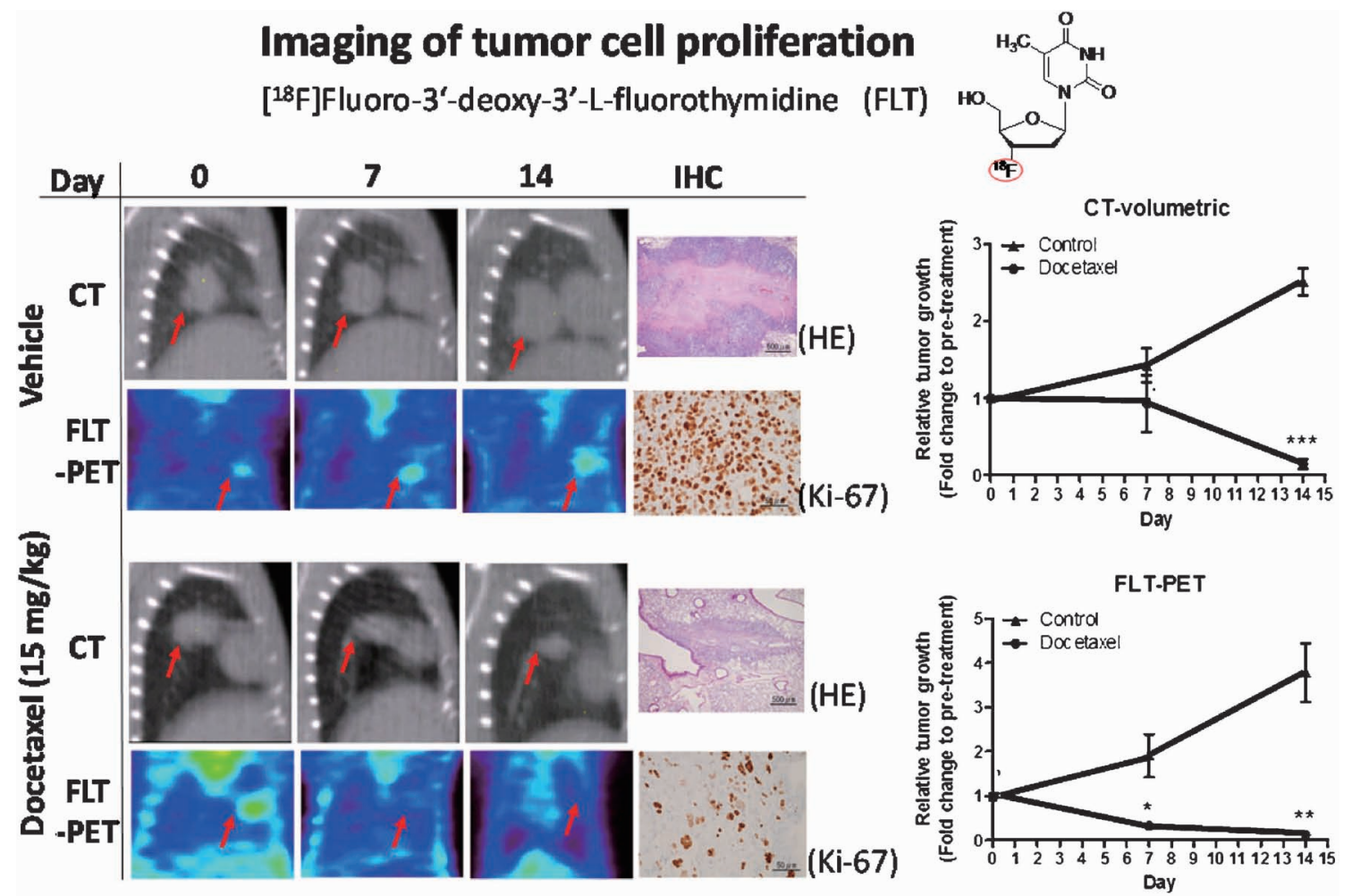

Fig. 2. Quantitative Evaluation of Anti-cancer Drug Efficacy on Lung Tumor Progression Monitored by FLT-PET and CT

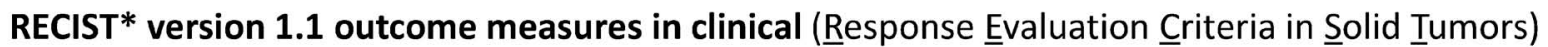
Measurable: Must be accurately measured in at least one dimension (longest diameter in the plane of measurement is to be recorded)....

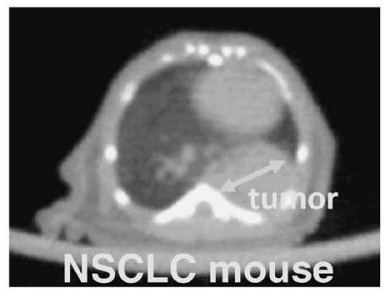

3D Volume try vs. 1D Diameter

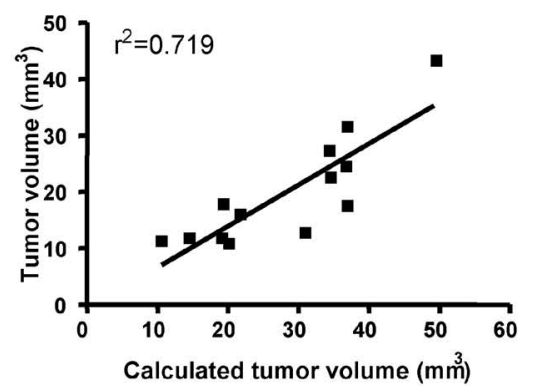

Calculated tumor volume $=\left(4 \pi(\text { diameter } / 2)^{3}\right) / 3$

\section{Response rate}

$>\mathrm{CR}$ (complete response) $=$ disappearance of all target lesions

$>P R($ partial response $)=$ $30 \%$ decrease in the sum of the longest diameter of target lesions

$>\mathrm{PD}$ (progressive disease $)=$ $20 \%$ increase in the sum of the longest diameter of target lesions

$>$ SD $($ stable disease $)=$ small changes that do not meet above criteria

Fig. 3. RECIST Criteria in Pre-clinical Study 
処理にて腫瘍体積を算出する方法の関係を検討した ところ，良好な相関を示すことが判明した(Fig. 3).

3. 抗がん風の開発における YM155 と ${ }^{11} \mathrm{C}$ 標識 体 YM155 の PET 試験

YM155 はアステラス製薬により創成されたがん 細胞に広く発現が認められるサバイビンを標的にし た低分子化合物であり, ${ }^{4}$ 国内及び米国にて固形が んあるいはリンパ腫の被験者における第 I 相臨床試 験が終了し, 5,6) 米国及び EU では第 II 相臨床試験 までも終えている，前臨床薬理試験デー夕から，腫 瘍中の YM155 存在量が腫瘍に対する効果を規定す る因子であることが強く示されていることより，腫 瘍中の YM155 存在量を非侵襲的に評価できる優れ た方法として YM155 の ${ }^{11} \mathrm{C}$ 標識体 $\left.{ }^{11} \mathrm{C}-\mathrm{YM} 155\right)$ を用いた PET 試験の科学的妥当性は高い。ささらに, YM155 はマウスやヒトにおいて，ほとんど未変化 体のまま排泄される特徵が報告7)されているため （特に PET 試験の測定時間内）, ${ }^{11} \mathrm{C}-\mathrm{YM} 155 \mathrm{PET}$ 試 験にて可視化されている放射線は YM155 自体の未 変化体を追跡していることになる。一般的に PET 試験の弱点である ${ }^{11} \mathrm{C}-\mathrm{YM} 155$ 未変化体と ${ }^{11} \mathrm{C}-\mathrm{YM} 155$
代謝物の区別がつかないという問題点の議論をする 必要性がない化合物であると言える，われわれは， Fig. 4 に示すように, YM155 の PET 標識体である ${ }^{11} \mathrm{C}-\mathrm{YM} 155$ の合成に成功し, ${ }^{8)}$ これを YM155 に感 受性を示す腫瘍による担がんマウスへ投与すること で， ${ }^{11} \mathrm{C}-\mathrm{YM} 155$ の腫瘍への集積を定量化すること ができた。一方，YM155 に抵抗性を有する腫瘍に おける担がんマウスでは, ${ }^{11} \mathrm{C}-\mathrm{YM} 155$ の腫瘍集積は 有意に低かったことにより， ${ }^{11} \mathrm{C}-\mathrm{YM} 155$ を用いた PET 試験は薬効予測イメージングバイオマーカー としての可能性が示唆された。さらに, ${ }^{11} \mathrm{C}-\mathrm{YM} 155$ を健常カニクイザルへ投与し，PET 試験による薬 物の全身組織分布を評価したところ，肝臓，腎臓と 膀胱を除いたすべての正常組織において ${ }^{11} \mathrm{C}-\mathrm{YM} 155$ はほとんど集積しないことが明らかとなった。これ は，肝臓がん，腎臓がんと膀胱がん以外の肺がん， 悪性リンパ種, 乳がん, メラノーマなどは ${ }^{11} \mathrm{C}$ YM155 の正常組織への移行性が低いことから腫瘍 集積との高いコントラストが期待できるため, 臨床 PET 試験が有効である可能性が考えられる，興味 深いことに，第 I 相臨床試験の結果より YM155 の

\section{Synthesis of ${ }^{11} \mathrm{C}-\mathrm{YM} 155$ with ${ }^{11} \mathrm{C}$-methyl triflate}
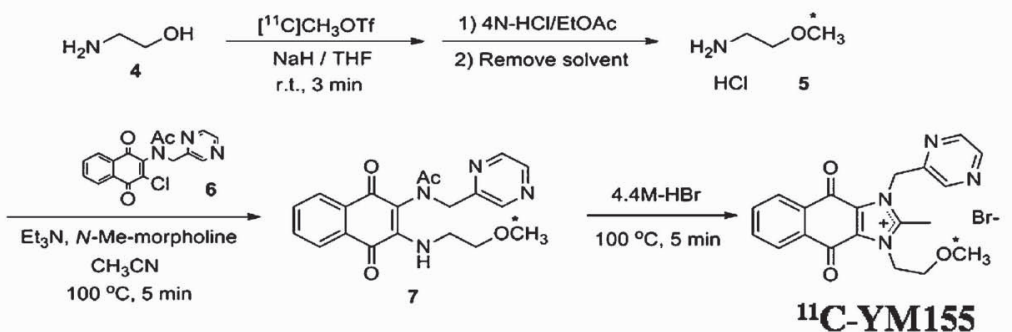

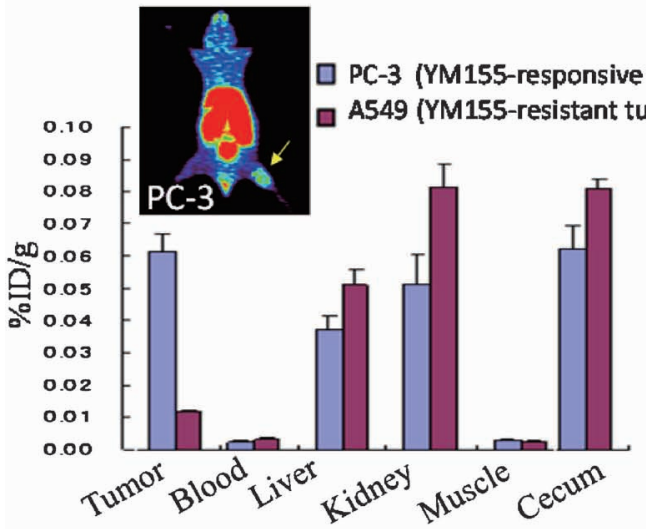

a) Tumor uptake of ${ }^{11} \mathrm{C}-Y M 155$ in mice with tumor

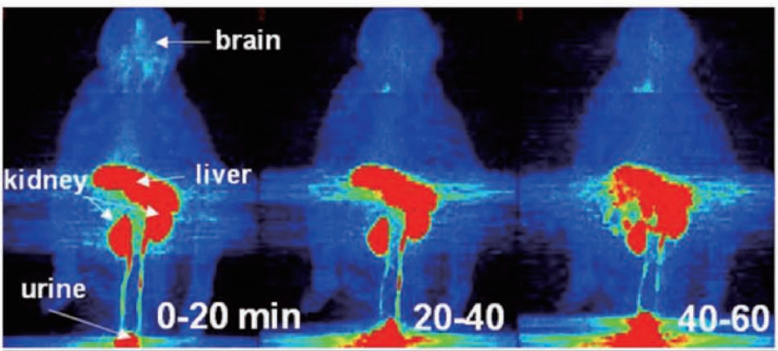

b) Wholy-body distribution of ${ }^{11} \mathrm{C}-\mathrm{YM} 155$ in healthy Cynomolgus Monkey

Fig. 4. Whole Body PET Imaging of ${ }^{11} \mathrm{C}-\mathrm{YM} 155$ in Preclinical Study 
1. Radioactive Drug Research Committee (RDRC);

- No IND, the study aim is Biodistribution only (cancer patients), IIT -Small scale $\mathrm{N}=30$ or less, this is NOT FIM study. Form FDA 2915 【Dosimetry】

2. elND; Microdosing study

- eIND will be approved within 60 days, the study aim is Biodistribution only (cancer patients). FIM study as a pre Phase 1.

【Dosimetry】,【Extended single-dose toxicity study】

3. IND; $\left[{ }^{11} \mathrm{C},{ }^{18} \mathrm{~F}\right] \mathrm{drug}-\mathrm{PET}$ for prediction of the drug treatment response. - IND cross-reference and investigational drug will be needed. $\cdot\left[{ }^{11} \mathrm{C}{ }^{18} \mathrm{~F}\right]-\mathrm{PET}$ study will be combined with drug chemotherapy [IND】, [Investigational drug】, 【Safety monitoring】

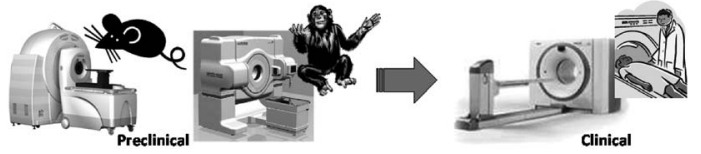

Fig. 5. PET Imaging Research Preclinical to Clinical

認容性は腎臓が悲鳴をあげる用量にて規定されてい ることとサルの ${ }^{11} \mathrm{C}-\mathrm{YM} 155$ による PET 試験が示す 腎臓への高い薬剤集積の結果はよく一致している. これらの ${ }^{11} \mathrm{C}-\mathrm{YM} 155$ による前臨床 PET 試験の結果 を基に，探索臨床 PET 研究や臨床 PET 試験への 応用を検討する場合, Fig. 5 にまとめられた 3 つ方 法が考えられる. Radioactive Drug Research Committee (RDRC) は, U.S. Food and Drug Administration（FDA）により認可を受けた施設の RDRC の承認により医師主導の下に実施される臨床 PET 研究であるため，IND は不要である，しかしなが ら，PETトレーサー量としてのマイクロドーズ投 与においても，その薬理活性を示さないことをこれ までのヒトへの投与実績から証明する必要があるた め，本試験が FIM であってはならない。 また，放 射性薬物としての PET 標識体を投与するので，内 部被ばく線量の情報も必要であり, 試験目的は全身 分布試験に限定され，試験規模も 30 人以内と制限 がある．FDA から eIND の取得による臨床 PET 試 験については，通常 eIND は FDA へ申請後 60 日 以内に承認され, 試験目的は全身分布試験に限定さ れるが，前臨床の拡張型単回毒性試験を実施するこ とで, 第 I 相臨床試験の前に FIM 試験として実施 することが可能である。開発化合物が第 I 相臨床試 験以降の段階にあれば，既にFDA より取得してい る IND をPET 試験用に cross-reference することも 可能と思われる.

${ }^{11} \mathrm{C}-\mathrm{YM} 155$ の臨床 PET 研究実施の意義ついては, 以下のようにまとめられる.

抗がん薬は副作用を伴うものであるので，患者さ
んの立場からはその薬が本当に自分のがんにとって 有効かどうかの判定は重要となる．薬剤の作用機序 にかかわらず，がんに対して有効性を示すために は，抗がん剂が当該病巣部位に一定量以上到達する ことは必須であり，それを事前に確認できる診断法 と組み合わされた治療は理想的なものであることは 言うまでもない。ささら，がん患者さんにとって腫 瘍発見から有効な治療の開始までの時間はとても貴 重であるので，効かない抗がん剤治療を漫然と受け ることによる時間のロスは，奏功する可能性のある 他の治療機会を奪うことになり，とても深刻な問題 点でもある．本 PET 試験のように，抗がん剤の治 療効果の判定を 1 日の PET 試験結果にて予測でき る可能性があるのであれば，患者さんの治療機会を 奪うことなく迅速に最適な治療法を見い出す手法と なり，その実施意義は大きいと思われる。抗がん剂 に対する感受性予測という観点からは，biopsy（生 検）により摘出した腫瘍の病理診断を行う方法がこ れまでは一般的であると思われるが， biopsy 検査 は，1）患者に痛みを伴う方法であること，2）摘出 術による感染症リスク，また 3）へテロな細胞集団 である腫瘍を摘出する精度の問題点や 4）原発巣等 の一部の摘出腫瘍からでは転移巣を含めた摘出部以 外の正確な情報を得るには不十分であるといつた種 々の問題点がある。これに対して，本試験法の PET イメージングは，非侵襲的な測定方法である ことに加えて，全身スキャンによる診断方法である ことから原発腫瘍のみならずすべての転移腫瘍をも 包括した診断が可能である。 また，PETイメージ ングはがんの微小環境を含めた状態での抗がん薬の 取り込み量を評価できることに加えて, PETイ メージングの特長である定量性の高さ, 感度のよさ を合わせて考慮すると多くの利点を有する診断方法 であると言える，近年，開発される薬剤の多くは分 子標的治療薬であり，腫瘍における標的分子の発現 量あるいは機能量に依存した薬効を発現するため, その必要性はますます高まりつつある. Figure 6 に 代表的な抗がん剤の PET 標識体をまとめた。 コン ベンショナルな抗がん剂から抗体医薬，そしてチロ シンキナーゼの分子標的薬まで幅広い研究が行われ ていることがわかる. PET 試験による ${ }^{11} \mathrm{C}$-erlotinib の肺がん患者さんの腫瘍への集積を erlotinib 治療 に対する奏効予測マーカーとして目指すものであ 


\section{Tyrosine kinase inhibitors}

$\left[\mathrm{N}-{ }^{11} \mathrm{C}\right.$-methyl] Imatinib (Glivec)

$\left[{ }^{11} \mathrm{C}\right]$ Gefitinib (Iressa)

$\left[{ }^{18} \mathrm{~F}\right]$ Gefitinib (Iressa)

$\left[{ }^{18} \mathrm{~F}\right]$ Dasatinib (Sprycel)

$\left[{ }^{18} \mathrm{~F}\right]$ Sunitinib (Sutent)

$\left[{ }^{11} \mathrm{C}\right]$ Erlotinib (Tarceva)

\section{Monoclonal antibodies}

$\left[{ }^{64} \mathrm{Cu}\right]$ DOTA-Cetuximab (Erbitax)

[ $\left.{ }^{89} \mathrm{Zr}\right]$ Bevacizumab (Avastin)

[ ${ }^{64} \mathrm{Cu}$ ]DOTA-Rituximab (Rituxan)

[ ${ }^{89}$ Zr]Trastuzumab (Herceptin)

\section{Others}

${ }^{18}$ F]Fluoropaclitaxel (Taxol)

[ $\left.{ }^{11} \mathrm{C}\right]$ Docetaxel (Taxotere)

5-[ $\left.{ }^{18} \mathrm{~F}\right]$ Fluorouracil (5-FU)

$\left[{ }^{18} \mathrm{~F}\right] \mathrm{Fluorocyclophosphamide}$

$\left[{ }^{13} \mathrm{~N}\right]$ Cisplatin

$\left[{ }^{13} \mathrm{~N}\right]$ Gemcitabine (Gemzar)

$\left[{ }^{11} \mathrm{C}\right] \mathrm{N}$-2 (dimetylamino)ehtylacridine-4-carboxamide
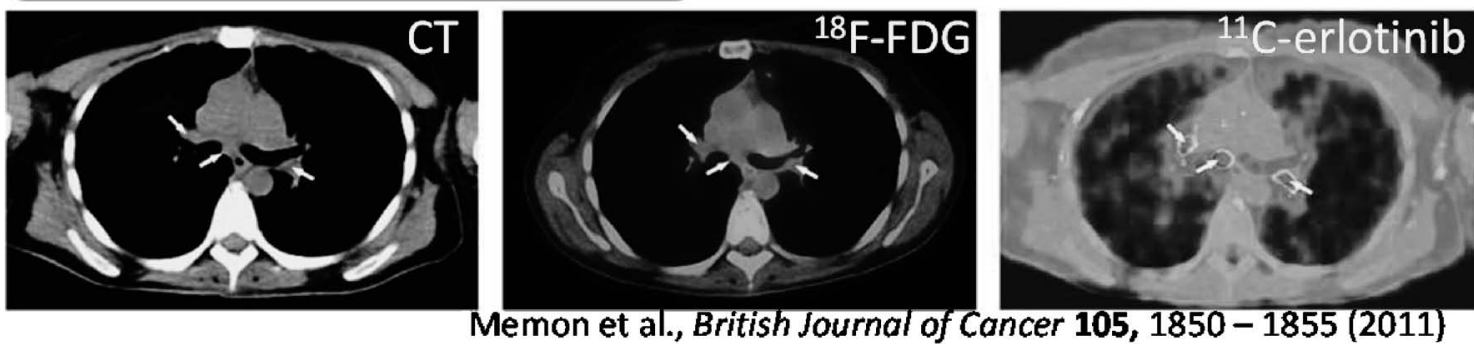

Fig. 6. Positron-labeled Anticancer Drugs

る. ${ }^{9)}$ Personalized Medicine Coalition (PMC) から の “The case for Personalized Medicine," 3rd edition ${ }^{10)}$ によれば，数年前までに治療薬と Companion diagnostics（CDx）がセットで添付文書に記 載されている薬は抗がん剂以外も含めてもワルファ リンの CYP 検査, EGFR 変異などたった 5-6 個だ ったと思われるが，現在では抗がんにおけるProspective に薬効と診断がセットになった治療がこれ ほどまでに増えている現状も参考にするべきであろ う.

4. 薬物誘発性の中枢毒性（神経細胞死）として のイメージングバイオマーカー

薬物投与により誘発される中枢毒性，とりわけ神 経細胞死に関連する安全性の予兆マーカーとして, 現在までに血液中や尿中からのパラメーターとして のバイオマーカーは一切存在しない。言い換えれ ば，病理検査以外に神経細胞死の評価方法はなく, 言うまでもなく臨床試験で患者さんから脳組織を得 ることはほとんど不可能な検査である。そこで，わ れわれは中枢毒性が懸念される薬物の臨床開発にお いて，ヒトで神経細胞死をモニタリングできる予兆 イメージングバイオマーカーとして FDG-PET 試
験を検討した. MK-801 は選択的な非競合的 NMDA 受容体拮抗薬であり，単回投与で膨大部のような特 定部位に神経細胞の空胞変性や壊死を起こすことが 知られている．MK-801 によるラット脳への神経毒 性作用は用量依存的であり, Fig. 7 の HE 染色病理 像より $0.4 \mathrm{mg} / \mathrm{kg}$ の皮下投与 4 時間後では膨大部に 神経細胞の空砲化は起きるが，24 時間後では回復 し神経細胞壊死には至らない。一方, $1 \mathrm{mg} / \mathrm{kg}$ の高 用量の MK-801 投与では 4 時間後に膨大部の神経 細胞に空砲化がみられ，さらに 24 時間後では神経 細胞壊死まで観察される，われわれは，MK-801に よる神経毒性のイメージングバイオマーカーとして の FDG-PET について評価したところ， $0.4 \mathrm{mg} / \mathrm{kg}$ から $1 \mathrm{mg} / \mathrm{kg}$ の MK-801 投与 4 時間後に空砲化変 性が惹起される膨大部で，FDGの特異的な集積が 起こることを観察した。また，FDG の膨大部への 集積は $30 \mathrm{mg} / \mathrm{kg}$ のスコポラミン投与により神経細 胞の空砲化変性を抑制したときにはみられなかった ことより，FDG-PET の集積と HE 染色による病理 像としての神経細胞空砲化変異は非常によく一致す ることも判明した。このように，FDG-PET は回復 可能なレベルの神経細胞空砲化の変異を MK-801 


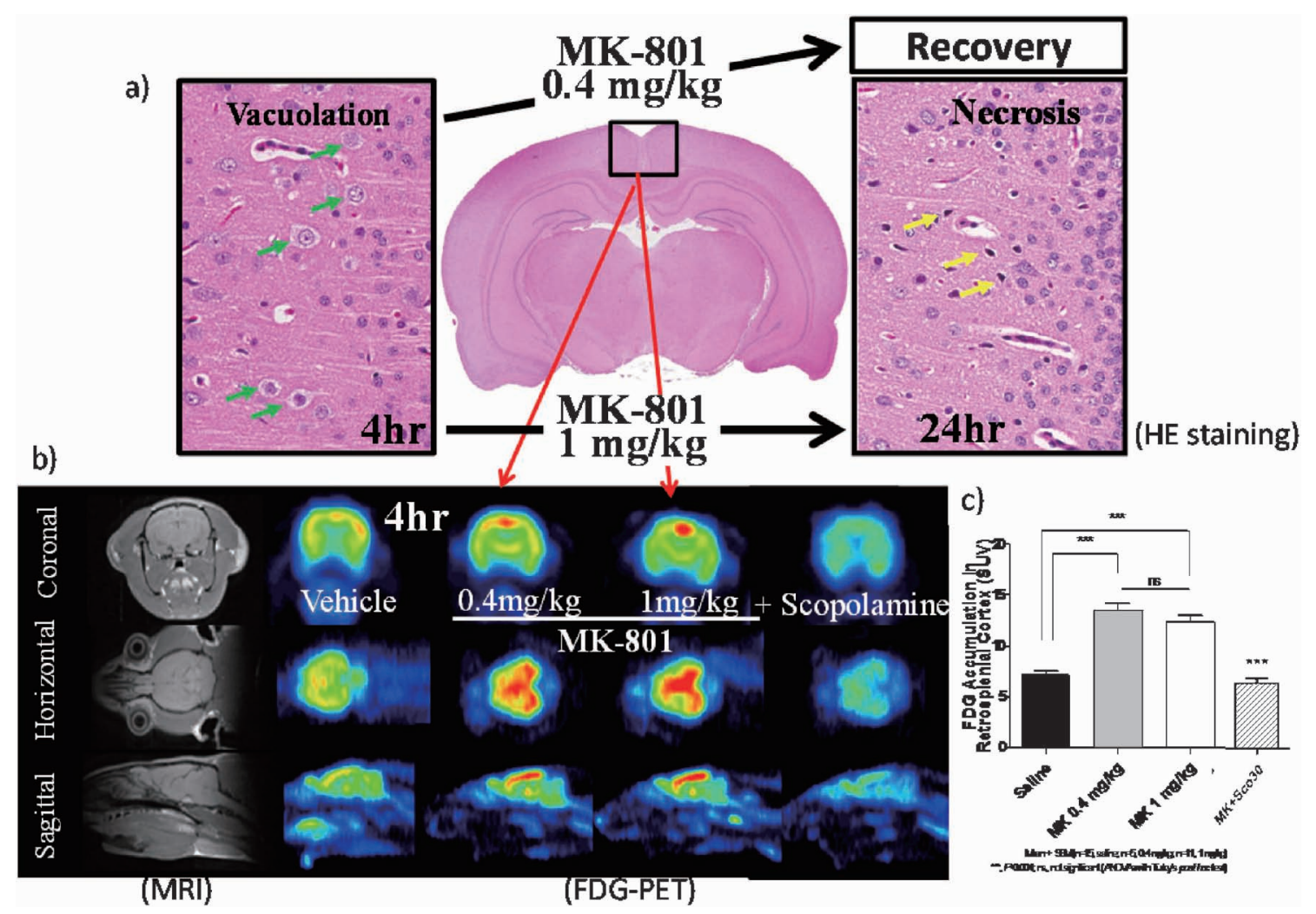

Fig. 7. FDG-PET as an Imaging Biomarker to MK-801-induced Neurotoxicity

a) Histopathology in hematoxylin and eosin stain, b) FDG-PET/MRI brain images, c) Quantitative analysis of FDG-PET brain images.

投与後 4 時間後の時点で検出することが可能である ことから，FDG-PET は MK-801 による神経細胞壊 死に対するイメージングバイオマーカーとしての有 用性が考えられる。 サルについても同様の試験とし て，さらに 10 倍高用量である $10 \mathrm{mg} / \mathrm{kg}$ の MK-801 をサルへ投与した 4 時間後における FDG-PET 試 験では，脳のすべての部位において FDG の上昇は みられなかった。 MK-801 (10 mg/ $\mathrm{kg}$ の) 投与後 4 時間, 24 時間の病理評価の結果より，神経細胞の 空砲化変異も壊死もそれぞれ観察されなかったこと から，FDG-PET 試験の神経毒性のイメージングバ イオマーカーとしての妥当性が示唆された.

\section{5. まとめ}

本稿では，医薬品開発における分子イメージング 技術の導入として，PETやCTに注目したアプ ローチについて述べてきた．分子イメージングの技 術は，臨床評価方法を前臨床の動物実験に適用する ことによる臨床予測性の向上にむけたバイオマー カーとして期待される。開発薬物のPET 標識体に よる PET 試験は, 従来の血中薬物濃度からでは推 測することが難しい抗がん剂の腫瘍中薬物濃度や中
枢薬の脳内薬物濃度の測定において，とりわけその 貢献が期待されるところである。一方で, 分子イ メージング技術の課題点としては，高コスト，低ス ループット，画像解析（読影）など複雑な試験であ る，前臨床・臨床施設がともに限定される，申請時 における必須試験項目ではない，などの問題点も残 されている．特に，後期の臨床試験として分子イ メージング試験を実施する場合, Multi-center trials として, 撮像用カメラ等の種々の装置が異なる多施 設間における試験プロトコルの統一化など課題も多 い. 今後更なる Alzheimer's Disease Neuroimaging Initiative (ADNI), Osteo-Arthritis Imaging (OAI), Oncology Biomarker Quantification Initiative (OBQI) や The Health and Environmental Sciences Institute（HESI） などのイメージングコンソーシア ムの進展による “Standardization \& Harmonization \& Quantification”の課題克服が期待される. 最後 に，分子イメージング技術の新たな応用例の 1 つと して，イメージングによる個体での薬物作用機序 (Mode of Action) の可視化は，製品のコンセプト や差別化ポイントなどの理解の一助につながること 
から，市販後製品の魅力度向上への貢献も大いに期 待されるところである.

\section{REFERENCES}

1) Miyoshi S., Mitsuoka K., Nishimura S., Veltkamp S., "Radioisotopes-Applications in Bio-medical Science," Chap. 5, ed. by Singh N., InTech, Rijeka, 2011.

2) Shirakawa T., Mitsuoka K., Kuroda K., Miyoshi S., Shiraki K., Naraoka H., Noda A., Fujikawa A., Fujiwara M., Toxicol. Sci., 133, 1321 (2013).

3) Fushiki H., Miyoshi S., Noda A., Murakami Y., Sasaki H., Jitsuoka M., Mitsuoka K., Matsunari I., Nishimura S., Anticancer Res., 33, 4741-4749.

4) Nakahara T., Kita A., Yamanaka K., Mori M., Amino N., Takeuchi M., Tominaga F., Hatakeyama S., Kinoyama I., Matsuhisa A., Kudoh M., Sasamata M., Cancer Res., 67, 8014-8021 (2007).

5) Tolcher A. W., Mita A., Lewis L. D., Garrett C. R., Till E., Daud A. I., Patnaik A., Papadopoulos K., Takimoto C., Bartels P.,
Keating A., Antonia S., J. Clin. Oncol., 26, 5198-5203 (2008).

6) Satoh T., Okamoto I., Miyazaki M., Morinaga R., Tsuya A., Hasegawa Y., Terashima M., Ueda S., Fukuoka M., Ariyoshi Y., Saito T., Masuda N., Watanabe H., Taguchi T., Kakihara T., Aoyama Y., Hashimoto Y., Nakagawa K., Clin. Cancer Res., 15, 3872-3880 (2009)

7) Minematsu T., Iwai M., Umehara K., Usui T., Kamimura H., Drug Metab. Dispos., 37, 619628 (2009).

8) Murakami Y., Matsuya T., Kita A., Yamanaka K., Noda A., Mitsuoka K., Nakahara T., Miyoshi S., Nishimura S., Nucl. Med. Biol., 40, 221-226 (2013).

9) Memon A. A., Weber B., Winterdahl M., Jakobsen S., Meldgaard P., Madsen H. H., Keiding S., Nexo E., Sorensen B. S., Br. J. Cancer, 105, 1850-1855 (2011).

10) Personalized Medicine Coalition, "The Case for Personalized Medicine," 3rd ed., PMC, Washington DC, 2011. 